УДК 7.071.1./007:304

\section{Марія Глушко}

викладач кафедри менеджменту мистецтва, фахівець з комунікації відділу видавництва та інформації Львівської національної академії мистецтв

https://orcid.org/0000-0002-2335-259X

\section{Репрезентація творчості Еммануїла Миська на сторінках мистецьких часописів}

Анотація. Здійснено аналіз мистецьких часописів та інших періодичних видань з мистецтва в контексті репрезентації творчості знаного скульптора Еммануїла Миська, який посідає особливе місце в образотворчому мистецтві України. Подано короткий огляд публікацій у періодичних виданнях, котрі грунтовно знайомлять читача зі становленням та еволюцією творчого шляху Еммануїла Миська. Увагу зосереджено на цілісному аналізі статей мистецтвознавців, що описують творчість мистця, а також публікацій, що містять лише окремі згадки про нього.

Для дослідження обрано низку відомих вітчизняних журналів з мистецтва, газет, вісників тощо, що висвітлювали культурно-мистецькі події, а саме - журнал Національної спілки художників України «Образотворче мистецтво», журнал «Мистецтво», газета «Вільна Україна», «Вісник Львівської національної академії мистецтв», «Народознавчі зошити», «Мистецькі обрії» та інші. Окреслено низку тенденцій щодо викладу матеріалу про Е. Миська, через які можна стверджувати, що кожен з авторів спробував максимально висвітлити засадничі аспекти діяльності Е. Миська у царині монументально-декоративної скульптури та підкреслити його внесок у розвиток українського мистецтва. З'ясовано, що талант, педагогічна та громадська діяльність, людські якості мистця та його вплив на культуру і мистецтво не залишилися без уваги вітчизняних науковців, мистецтвознавців, дослідників, які у своїх працях, опублікованих на сторінках мистецьких часописів та інших періодичних видань, описують різні аспекти життя і творчості видатного українського скульптора, мистецтвознавця, педагога, громадського діяча. Виявлено потребу у створенні структурованого бібліографічного покажчика, який міститиме повний перелік статей, присвячених Е. Миськові, опублікованих від 1996 р., оскільки до зазначеного року видано «Бібліографічний покажчик», а основні положення та висновки статті можуть використовуватися при формуванні відповідних розділів нового «Бібліографічного покажчика», котрий стане своєрідною базою для молодих дослідників, що вивчатимуть творчість Е. Миська.

Ключові слова: мистецький часопис, періодичне видання, науковий збірник, творчий здобуток Еммануїла Миська, монументально-декоративна скульптура, портрет.

$\Pi^{2}$ остановка проблеми. Постать Емануїла Миська в системі культурно-мистецького життя важко переоцінити, оскільки це одна з найбільш значущих фігур культурного відродження 1990-х рр., яскравий представник мистецької еліти, видатний діяч культури і мистецтва, талановитий скульптор. Як писав Р. Яців: «Він став одним 3 найвідоміших реформаторів мистецького світу, розумів наскільки важливо повернутися до своїх витоків і дати європейську зорієнтованість українській культурі - того, що їй завжди було притаманне, але у радянські часи занедбано» [20, с. 9].

Актуальність теми зумовлена потребою здійснити комплексне дослідження форм репрезентації на сторінках мистецької періодики творчості провідного українського скульптора, педагога, активного учасника художнього процесу, представника львівської мистецької школи, громадського діяча Е. Миська, чия творчість стала об'єктом дослідження мистецтвознавців другої половини XX - початку XXI ст.

Мета статті - аналіз специфіки репрезентації творчих здобутків Е. Миська на сторінках мистецьких часописів, наукових збірників, газет, альманахів тощо.

Аналізуючи останні дослідження та публікації, доцільно виділити праці таких дослідників - О. Голубець [4], А. Чебикін [17; 18], В. Одрехівський [12], Р. Яців [20], Р. Шмагало [19], 
Г. Островський [13; 14], Я. Мисько [7-10] та інші, оскільки вони висвітлили особливості творчого методу Е. Миська, його внесок у розвиток мистецької освіти, позицію щодо формування молодих митців, вплив на розвиток культури загалом. Проте в ході дослідження не виявлено статей, які повною мірою виявляють особливості висвітлення творчості Е. Миська та форму подання опублікованих матеріалів на сторінках періодичних видань з мистецтва, що підкреслює актуальність роботи.

Виклад основного матеріалу. Детальний опис здобутків Е. Миська можна віднайти у каталогах, альбомах, енциклопедіях, довідниках, що присвячені життю і творчості митця, а також на сторінках мистецьких часописів та інших періодичних видань, частину з яких ми розглянемо. Повний перелік публікацій, виданих до 1996 р. знаходимо на сторінках видання «Еммануїл Мисько. Бібліографічний покажчик», укладачем якого $\epsilon$ Н. В Міц (Львів, 1996), який містить інформацію про основні дати життя і творчості; мистецькі твори (скульптура, рисунки); каталоги виставок, у яких брав участь Е. Мисько, інформація про інші виставки, каталоги яких не видавались; видання, статті, виступи у пресі; література про Е. Миська та його творчість [5].

Вважаємо за доцільне здійснити огляд найбільш грунтовних статей, опублікованих у період від 1950-х рр. і до 2019 р., за наступними критеріями: окремі згадки про Е. Миська в публікаціях про українську скульптуру та присвячені персонально йому статті, опубліковані на сторінках мистецьких часописів, наукових збірників, інших періодичних видань з мистецтва.

У процесі вивчення матеріалів, окрім індивідуальних статей про Е. Миська, виявляємо значну кількість публікацій на сторінках періодики з мистецтва, які містять лише окремі згадки в контексті висвітлення тенденцій розвитку культури чи мистецьких явищ кінця XX - початку XXI ст.

Серед перших статей, у яких згадують про ранній період творчості Е. Миська, слід згадати публікації на сторінках відомих і популярних на той час періодичних видань. Варто відзначити статті у журналі «Мистецтво» авторів В. Касіан та I. Катрушенко «Знамениті здобутки» (1959), у якій відзначено успішну працю молодого митця Е. Миська та інших скульпторів; Д. Янка «До зеніту планом»; стаття М. Батога, подана під загальною рубрикою «У художників України» у журналі «Творчество» (№ 8, 1960), теж вартує уваги, адже в ній подано короткий огляд виставки скульптури у Львівському музеї українського мистецтва, на якій також експонувалися твори Е. Миська.

Часто знаходимо статті на сторінках інших періодичних видань України, зокрема у газеті «Вільна Україна». 1962 року О. Ріпко написала коментар у газеті «Портрет сучасності: по залах республіканської художньої виставки «РадянськаУкраїна», у якій відзначено твори львівських скульпторів, зокрема портрет народної художниці УРСР О. Кульчицької ав торства Е. Миська. У 60-70-х рр. ХХ ст. у цьому виданні публікується низка статей із згадками про Е. Миська: Б. Горинь «Сучасна львівська скульптура», О. Чарновський «У руслі соціалістичного реалізму», Я. Гоян «Овиди сонячної дружби: Відкриття пам'ятника I. Я. Франкові у Дрогобичі», Д. Янко «До мистецького зеніту», Г. Печенівський «Проблеми львівського різця і пензля», Н. Опанасенко «На шляху шукань», А. Попов «Дерзання молодих митців: Нотатки критика», Р. Янишевський «Майстер портрета», Р. Соловчук «Навіки у бронзі». 1986 року (від 16 вересня) автор М. Мариняк пише про відкриття скульптурної композиції «Іван Франко і світова література», одним з авторів якого був Е. Мисько. Цього ж року в серпні О. Пеленська також згадала про Е. Миська при описі відкриття обласної художньої виставки, присвяченої 130-річчю від дня народження I. Франка [5].

Чимало згадок про Е. Миська надруковано на сторінках менш відомих газет і журналів, а саме - статті А. Німенка «В малярстві, графіці, скульптурі» у газеті «Прапор» (1966), П. Романюка «Звітують митці» у газеті «Ленінська молодь» (1967), В. Гая «Кузня митців» у журналі «Радянський журналіст» (1969).

у контексті нашого дослідження варто виокремити статті в журналі Національної спілки художників України «Образотворче мистецтво», у яких згадується Е. Мисько, а саме - автори В. Батіг «Дорогами творчих шукань» (1969), П. Говдя «Виставка українського 
мистецтва в Москві» (1972), О. Пеленська «Хроніка» (1973), О. Ріпко «Громадянська зрілість художника», Е. Сафонова «За велінням серця» (1974), П. Говдя «Героїка народного подвигу», Т. Максисько «Доробок львівських художників у медальєрстві», Р. Даскалова «Перша республіканська виставка медалей» (1975), А. Мороз «Скульптурний портрет» (1976), О. Сидор «Львів: 100 років львівського рисунка» (1981), В. Одрехівський «Пам’ятні місця Львова» (1982), В. Бородай «Українська скульптура сьогодні», В. Одрехівський «Монументально-декоративна скульптура львівських митців» (1983), О. Сидор «Львівський музей українського мистецтва», О. Говдя «Мовою пластики» (1984) та «Навічно в пам'яті народній» (1985), О. Лопухов «Утверджувати моральні й естетичні принципи радянського суспільства» (1986), В. Глинчак «Довгий шлях до відродження» (1989), Д. Крвавич «Конференція з сакрального мистецтва» (1993) та ін.

Аналізуючи статті, присвячені винятково творчості Е. Миська, опубліковані на сторінках мистецьких часописів від 60-х років, знову звернемося до публікацій у журналі «Образотворче мистецтво». Виділити та детальніше оглянути слід дві статті мистецтвознавця Григорія Островського про Е. Миська. У третьому числі журналу за 1973 р., матеріали якого присвячені загальному стану монументального мистецтва в Україні, у статті цього автора «Емануїл Мисько» розглядається творча діяльність львівського скульптора періоду 50-70-х рр. Мистецтвознавець більшою мірою розглядає діяльність скульптора у напрямку монументальної скульптури, проте стверджує також, що «інтенсивна та плідна робота в галузі монументальної скульптури, хоча, природно, і забирала багато часу та енергії, не заважала однак еволюції Миська як портретиста». Зокрема, автор виділяє портрет художника Павла Балли та переконує, що саме ця робота Е. Миська стала відправною точкою його як майстра психологічного портрету [13, с. 22-25].

Також Г. Островський у співавторстві із Наталією Маїк у журналі «Образотворче мистецтво» опублікували статтю про творчість скульптора Е. Миська та живописця С. Коропчака «Своєрідність творчого пошуку». Григорій Островський пише про незмінну центральну тему творчості митця - виділяє творчість як зміст і сенс життя, життя як діяння, творчість у найширшому розумінні, де людина представлена як свідомий творець духовних і матеріальних цінностей, будівничий нового світу. Розкриваючи нові грані обдарування митця, автор відзначає його ще вільніше та впевненіше володіння арсеналом портретної пластики та багатою палітрою психологічних барв [14, с. 17-19].

Окрім зазначених статей, Г. Островський опублікував інші матеріали про митця у каталозі виставки «Народний художник Еммануїл Мисько» (Київ, 1979), статтю «Портрети людей нашого часу» в журналі «Искусство» (Москва, 1999) та у виданні «Скульптура. Еммануїл Мисько» статтю «Погляд здалеку, крізь роки...» (Львів, 1999) та ін.

Головний редактор журналу «Образотворче мистецтво» та альманаху «Артанія» Микола Маричевський та Еммануїл Мисько 1999 р. мали розмову про історичні мистецькі процеси у Львові, про життя Львівської академії мистецтв, про що згодом опубліковано статтю у 1-2 числі журналу «Образотворче мистецтво» за 1999 р. Серед питань, висвітлених у публікації, перше стосувалося початків життєвого і творчого шляху мистця, як і чому його доля пов'язалася саме з образотворчим мистецтвом. Також Е. Мисько розповів про своє походження, період творчого становлення, про мистецьку атмосферу у Львові, знайомство з I. Северою та О. Кульчицькою; присутні рефлексії на тему мистецької освіти та проблеми політики в освітній галузі і академії, і держави загалом; Е. Мисько висловив свою позицію як українець, мистець і ректор, наголосив на необхідності розбудови державної програми розвитку культури. Загалом, М. Маричевський в інтерв'ю підкреслив, що Е. Мисько у творчості, у сфері керівництва мистецьким навчальним закладом та у своїй громадській позиції завжди був вірний собі й своїм поглядам [16, с. 3-5].

У рубриці «Ім'я в мистецтві» цього ж числа журналу бачимо ще одну статтю про Е. Миська - «Здатність розкрити душу людини», автором якої була Валентина Рубан. Авторка зараховує Е. Миська до видатних українських скульпторів другої половини XX ст., відзначаючи його за масштаби обдарування, широту й багато- 
Репрезентація творчості Еммануїла Миська на сторінках мистецьких часописів

гранність творчого діапазону, високий професіоналізм. «В його творах глибоко і вмістко втілилися типові риси часу. Утвердження власного бачення людини і світу, прагнення виразної і органічної пластичної форми, сповненої внутрішньої енергії, - характерні ознаки почерку Майстра», - пише В. Рубан про Е. Мись ка [15, с. 6-7].

Знаходимо низку статей у «Віснику Львівської національної академії мистецтв» (далі «Вісник ЛНАМ»), який виходить від 1990 р. і $\epsilon$ фаховим виданням з мистецтвознавства та культурології. Наприкінці XX - на початку XXI ст. тут опубліковано кілька статей авторства відомих вітчизняних науковців, присвячених творчості Е. Миська, а саме - статті В. Бадяка «Еммануїл Мисько: найкраща робота попереду» (Вип. 10, 1999, с. 5-21) [1], О. Голубця «Майстер портретного жанру» (Вип. 10, 1999, с. 26-30) [4], Д. Крвавича «Еммануїл Петрович Мисько - митець, соратник, видна постать сучасності» (Вип. 12, 2001, с. 283-295) [6], А. Чебикіна «Вплив академіка Еммануїла Миська на розвиток освіти мистецьких навчальних закладів» (Вип. 2, 2001, с. 296-301) [17]. У згаданих статтях розглянуто постать Е. Миська, систематизовано факти 3 його життя і творчості, проаналізовано відомі та нововідкриті твори митця.

Варто відзначити, що в період від 2000 р. i до сьогодні традиція відображення творчості мистця на сторінках «Вісника ЛНАМ» зберігається, у цьому контексті розглянуто статтю Яреми Миська «Меморіальна скульптура Еммануїла Миська: специфіка художньо-образних вирішень», присвячену розкриттю одного з напрямків творчої діяльності Е. Миська, а саме - меморіальній пластиці. Автор здійснив спробу встановити взаємозв'язки з тогочасною мистецькою практикою в межах країн соціалістичного табору та окреслив впливи формалістичних експериментів у скульптурній пластиці країн Західної та Центральної Європи. Яремі Миську вдалося виявити основні засади творчого методу митця в розкритті образу осіб, пам'ять яких він увічнював у скульптурах [7, с. 368-375].

Слід розглянути також статтю Я. Миська у «Віснику Харківської державної академії дизайну і мистецтв» «Портрети представників української інтелігенції у творчості Емману- їла Миська 1998-1999 рр.: образно-пластичні особливості» (2014), де здійснено комплексний аналіз структурно-образних особливостей серії портретів представників української інтелігенції, створених упродовж останніх років його життя - 1998-1999 рр. Зокрема, автор виділив специфіку образних трактувань і концептуальних засад цієї серії з огляду на особливості професійних і особистісних характеристик портретованих. Варто відзначити здійснений у дослідженні Я. Миська порівняльний аналіз ключових зразків серії, за допомогою якого йому вдалося відзначити характер і особливості відображення творчої манери Е. Миська, його методу роботи з натурою, а також особливості відтворення внутрішнього світу персонажів. Відповідно, основну увагу автор зосередив на характеристиці формально-пластичних вирішень, застосованих у скульптурних зображеннях авторитетних представників української культури й духовенства М. Лабуньки, I. Музички, І. Хоми, В. Стернюка та Й. Сліпого. Окрім того, дослідник відзначає індивідуалізовані композиційні, формотворчі та психологічні акценти, які зробив Е. Мисько в кожному із зазначених у статті портретів [9, с. 86-90].

У публікації «Образно-пластична візуалізація національної традиції у творчості Еммануїла Миська на прикладі серій скульптурних портретів» (2014) у «Наукових записках Національного університету «Острозька академія» Я. Мисько відзначив важливий характерний момент у творчості Е. Миська, а саме - митець звертався не тільки до виявлення внутрішнього світу, емоційних особливостей персонажів, але й до розкриття соціокультурного контексту їхнього буття, специфіки національної проблематики (і на рівні пластики, композиції, і концепції твору). Також він відзначив, що творчий пошук українського скульптора може стати не тільки вагомим явищем для вивчення передумов формування етнокультурної самоідентифікації митця другої половини ХХ ст., але й продемонструвати вектори адаптації сучасних творчих досвідів українських скульпторів початку XXI ст. [8, с. 347-348].

Стаття авторства Я. Миська «Скульптурні портрети українських письменників у творчості Еммануїла Миська: образність та плас- 
тичні особливості» на сторінках «Народознавчих зошитів» (2017) також варта уваги, адже тут проаналізовано образно-пластичні особливості скульптурних портретів українських письменників, які створив Е. Мисько. Важливо, що авторові вдалося встановити особливості творчого методу скульптора, а також його послідовну візуалізацію у кожному образі [10, с. 1177-1180].

На окрему увагу заслуговує випуск «Вісника Закарпатської академії мистецтв», виданого (2018) до 90-річчя від дня народження Е. Миська, у якому опубліковано десять статей про життя, творчість, педагогічну та громадську діяльність митця. Авторами статей $є$ відомі українські діячі: академіки, народні художники України, доктори і кандидати наук, ректори Львівської і Закарпатської академії мистецтв, ректор Національної академії образотворчого мистецтва і архітектури, дружина митця та ін.: I. Небесник «Слово про Еммануїла Миська» [11], А. Чебикін «Незгасне світло долі» [18], А. Бокотей «Е. Мисько - значима постать українського відродження 1990-х рр.» [2], Р. Яців «Скульптор Еммануїл Мисько: світло долі» [20], В. Одрехівський «Особливості пластики Еммануїла Миська» [12], Р. Шмагало «Творчо-педагогічний феномен Еммануїла Миська» [19], М. Мушинка «Мої взаємини з Еммануїлом Петровичем Миськом», І. Дідик «Еммануїл Мисько - ключова постать мистецької еліти України», В. Микита «Спогади про побратима», Віолетта Мисько «Таким ми його пам’ятаємо...» [3].

Кожна із статей порушує важливу проблематику. Особливості творчого шляху Е. Миська розкриває В. Одрехівський і вказує на те, що природа пластичного формотворення митця $€$ багатошаровою і становить сплав класичних традицій європейської скульптури Відродження, бароко, тенденцій пластики XX ст. «Цей творчий досвід попередніх поколінь став для скульптора лише плідним грунтом, що він у кожній роботі по-новому творчо опрацьовував, перепускав через розум і серце, і витворив свій неповторний стиль, сповнений сили і внутрішньої енергетики, стиль, співзвучний часові і який безпомилково вгадується як «стиль Еммануїла Миська», - зазначає В. Одрехівський [12, c. 9-11].

Значна частина авторів відзначають, окрім творчої майстерності, ще й патріотизм митця та ставлення до рідної землі. Андрій Чебикін згадує: «Усім своїм життям, талановитою творчістю Еммануїл Петрович являв високий взірець вірного служіння рідній землі і народові України» [18, с. 7]. Охарактеризував громадську позицію митця і Р. Яців: «Еммануїл Мисько був членом Народного руху у Львові. Він разом $з$ іншими видатними постатями відіграв велику роль для мобілізації нашого національно-культурного організму» [20, с. 9].

Відзначено також внесок Е. Миська в розвиток мистецької освіти. «Еммануїл Петрович бачив і розумів проблеми художньої освіти... Він знав усе про нашу матеріальну базу, кадри і небезпеку закриття, оптимізації чи приєднання до культосвітніх закладів, що могло стати похороном художньої освіти. Саме тому він допомагав нам у реформуванні училищ у коледжі, таким чином допомагаючи нашому виживанню», - згадує I. Небесник [11, с. 6]. Ростислав Шмагало, який досліджує проблематику мистецької освіти, писав: «Як організатор мистецької освіти, Е. Мисько докладав великих особистих зусиль для розбудови ¥ї в широкому територіальному вимірі. Це, насамперед, реалізація ідеї міжрегіонального навчального комплексу, що об'єднав мистецькоосвітні осередки Львова, Косова, Ужгорода, Вижниці, Підбужа» [19, с. 11-14].

Висновки. Непересічний талант, педагогічна та громадська діяльність, людські якості Еммануїла Миська та його вплив на культуру і мистецтво, на мистецьку освіту, на творчість багатьох видатних митців незаперечні та не залишилися без уваги. Вітчизняні мистецтвознавці на сторінках мистецьких часописів та інших періодичних видань відтворюють ключові моменти життя і творчості видатного мистця. Абсолютна більшість наукових публікацій про Е. Миська характеризують його винятково як видатного українського скульптора, мистецтвознавця, педагога, громадського діяча, керівника, патріота своєї справи і своєї країни. Підсумовуючи, можемо стверджувати, що на сторінках періодичних видань, які порушують мистецькі теми, знаходимо значну кількість згадок про Е. Миська. Позитивним у час диджіталізації $є$ те, що чимало статей оцифровано та опубліковано в мережі Інтернет на 
Репрезентація творчості Еммануїла Миська на сторінках мистецьких часописів

спеціалізованих онлайн-платформах, проте немає комплексного й структурованого переліку публікацій, які висвітлюють діяльність Е. Миська від 1996 р. Вивчення особливостей репрезентації творчості митця на сторінках періодичних видань, присвячених проблемам образотворчого та декоративно-прикладного мистецтва, зокрема специфіки окремих статей, дає змогу формувати структурно цілісне дослідження, присвячене визначним постатям, зокрема, львівського мистецького осередку. Основні положення та висновки цієї статті можуть використовуватися при формуванні відповідних розділів повного структурованого «Бібліографічного покажчика», що стане своєрідною базою для молодих дослідників творчості Еммануїла Миська.

1. Бадяк В. Еммануїл Мисько: найкраща робота попереду. Вісник Львівської академї мистецтвв. Вип. 10. Львів : ЛАМ, 1999. С. 5-21.

2. Бокотей А. Е. Мисько - значима постать українського відродження 1990-их рр. Вісник Закарпатської академії мистецтв. 2018. Вип. 11. С. 8.

3. Вісник Закарпатської академії мистецтв / гол. ред. Небесник I. І. 2018. Вип. 11. С. 6-22.

4. Голубець О. Майстер портретного жанру. Вісник Львівської академї̈ мистецзтв. 1999. Вип. 10. С. 26-30.

5. Еммануїл Мисько: Бібліограф. покажчик / відп. ред. С. О. Черепанова ; уклад. Н. В. Міц ; М-во освіти України, Львівська академія мистецтв. Львів : Каменяр, 1996. 60 с.

6. Крвавич Д. Еммануїл Петрович Мисько - митець, соратник, видна постать сучасності. Bicник Львівської академії мистецзтв. 2001. Вип. 12. С. 283-295.

7. Мисько Я. Меморіальна скульптура Еммануїла Миська: специфіка художньо-образних вирішень. Вісник Львівської національної академії мистеитве. 2012. Вип. 23. С. 368-375.

8. Мисько Я. Образно-пластична візуалізація національної традиції у творчості Еммануїла Миська на прикладі серій скульптурних портретів. Наукові записки Національного університету «Острозька академія». Серія : Культурологія. 2014. Вип. 15(2). С. 347-348. URL : http://nbuv. gov.ua/UJRN/ Nznuoak1_2014_15(2)__50. (дата звернення: 15.04.2019).

9. Мисько Я. Ю. Портрети представників укра- їнської інтелігенції у творчості Еммануїла Миська 1998-1999 рр.: образно-пластичні особливості. Вісник Харківської державної академії Әизайну і мистецтвв. 2014. № 6. С. 86-90.

10. Мисько Я. Ю. Скульптурні портрети українських письменників у творчості Еммануїла Миська: образність та пластичні особливості. Народознавчі зошити. 2017. № 5 (137). С. 11771180.

11. Небесник I. Слово про Еммануїла Миська. Bicник Закарпатської академії мистеитв. 2018. Вип. 11. C. 6.

12. Одрехівський В. Особливості пластики Еммануїла Миська. Вісник Закарпатської академії мистеитв. 2018. Вип. 11. С. 9-11.

13.Островський Г. Еммануїл Мисько. Образотворче мистецзвво. Київ : Нац. спілка художників України, 1973. № 3. С. 22-25.

14. Островський Г. Своєрідність творчого пошуку. Образотворче мистецтво. Київ : Нац. спілка художників України, 1985. № 2. С. 17-19.

15. Рубан В. Здатність розкрити душу людини. Образотворие мистецтво. Київ : Нац. спілка художників України, 1999. № 1-2. С. 6-7.

16. Україна - як свобода волі для мистця. Образотворче мистеитво. Київ : Нац. спілка художників України, 1999. № 1-2. С. 3-5.

17. Чебикін А. Вплив академіка Еммануїла Миська на розвиток освіти мистецьких навчальних закладів. Вісник Львівської академії мистеитвв. 2001. Вип. 12. С. 296-301.

18. Чебикін . Незгасне світло долі. Вісник Закарпатської академї мистеизтв. 2018. Вип. 11. С. 7.

19. Шмагало Р. Творчо-педагогічний феномен Еммануїла Миська. Вісник Закарпатської академії мистеитев. 2018. Вип. 11. С. 11-14.

20. Яців Р. Скульптор Еммануїл Мисько: світло долі. Вісник Закарпатської академії мистеитев. 2018. Вип. 11. С. 9.

\section{References}

1. Badiak, V. (1999). Emmanuil Mysko: naikrashcha robota poperedu [Emmanuil Mysko: The best work ahead]. Visnyk Lvivskoi akademii mystetstv Bulletin of the Lviv Academy of Arts, 10, 5-21 [in Ukrainian]

2. Bokotei, A. (2018). E. Mysko - znachyma postat ukrainskoho vidrodzhennia 1990-ykh rr. [E. Mysko - a significant figure of Ukrainian revival in the 1990s.]. Visnyk Zakarpatskoi akademii mystetstv Bulletin of the Transcarpathian Academy of Arts, 
11, 8 [in Ukrainian]

3. Nebesnyk, I. (Ed.), (2018), Visnyk Zakarpatskoi akademii mystetstv - Bulletin of the Transcarpathian Academy of Arts, 11, 228 [in Ukrainian]

4. Holubets O. (1999). Maister portretnoho zhanru [Master of the portrait genre]. Visnyk Lvivskoi akademii mystetstv - Bulletin of the Lviv Academy of Arts, 10, 26-30 [in Ukrainian]

5. Cherepanova, S. O. (Ed.). (1996). Emmanuil Mysko: Bibliohrafichnyi pokazhchyk [Emmanuil Mysko: Bibliographic index]. Lviv : «Kameniar» [in Ukrainian].

6. Krvavych, D. (2001). Emmanuil Petrovych Mysko - mytets, soratnyk, vydna postat suchasnosti [Emmanuil Mysko - artist, associate, prominent figure of modernity]. Visnyk Lvivskoi akademii mystetstv - Bulletin of the Lviv Academy of Arts, 12, 283-295 [in Ukrainian].

7. Mysko, Ya. (2012). Memorialna skulptura Emmanuila Myska: spetsyfika khudozhno-obraznykh vyrishen [The Emmanuil Mysko's Memorial Sculpture: Specificity of Artistic and Figurative Decisions.]. Visnyk Lvivskoi akademii mystetstv - Bulletin of the Lviv Academy of Arts, 23, 368-375 [in Ukrainian]. 8. Mysko Ya. (2014). Obrazno-plastychna vizualizatsiia natsionalnoi tradytsii u tvorchosti Emmanuila Myska na prykladi serii skulpturnykh portretiv [Figurative-plastic visualization of the national tradition in the work of Emmanuil Mysko on the example of a series of sculptural portraits]. Naukovi zapysky Natsionalnoho universytetu «Ostrozka akademiia» - Scientific notes of the Ostroh Academy National University, 15(2), 347-348 [in Ukrainian].

9. Mysko, Ya. Yu. (2014). Portrety predstavnykiv ukrainskoi intelihentsii u tvorchosti Emmanuila Myska 1998-1999 rr.: obrazno-plastychni osoblyvosti [Portraits of representatives of the Ukrainian intelligentsia in the work of Emmanuil Mysko 1998-1999: figurative and plastic features]. Visnyk Kharkivskoi derzhavnoi akademii dyzainu i mystetstv - Bulletin of Kharkiv State Academy of Design and Arts, 6, 86-90 [in Ukrainian].

10. Mysko, Ya. Yu. (2017). Skulpturni portrety ukrainskykh pysmennykiv u tvorchosti Emmanuila Myska: obraznist ta plastychni osoblyvosti [Sculptural portraits of Ukrainian writers in the work of Emmanuil Mysko: imagery and plastic features.]. Narodoznavchi zoshyty - National Notebooks, 5(137), 1177-1180 [in Ukrainian].
11. Nebesnyk, I. (2018). Slovo pro Emmanuila Myska [A word about Emmanuil Mysko]. Visnyk Zakarpatskoi akademii mystetstv - Bulletin of the Transcarpathian Academy of Arts, 11, 6 [in Ukrainian].

12. Odrekhivskyi, V. (2018). Osoblyvosti plastyky Emmanuila Myska [Features of Emmanuel Mysko Plastic]. Visnyk Zakarpatskoi akademii mystetstv - Bulletin of the Transcarpathian Academy of Arts, 11, 9-11 [in Ukrainian].

13. Ostrovskyi, H. (1973). Emmanuil Mysko [Emmanuil Mysko]. Obrazotvorche mystetstvo - Fine Arts, 3, 22-25 [in Ukrainian].

14. Ostrovskyi, H. (1985). Svoieridnist tvorchoho poshuku [Originality of creative search]. Obrazotvorche mystetstvo - Fine Arts, 2, 17-19 [in Ukrainian].

15. Ruban, V. (1999). Zdatnist rozkryty dushu liudyny [The ability to open the soul of man]. Obrazotvorche mystetstvo - Fine Arts, 1-2, 6-7 [in Ukrainian].

16. Marychevskyi, M. (Ed.), (1999). Ukraina - yak svoboda voli dlia mysttsia [Ukraine - as a free will for the artist]. Obrazotvorche mystetstvo - Fine Arts, 1-2, 3-5 [in Ukrainian].

17. Chebykin, A. (2001). Vplyv akademika Emmanuila Myska na rozvytok osvity mystetskykh navchalnykh zakladiv [The influence of Academician Emmanuil Mysko on the development of education of art schools]. Visnyk Lvivskoi akademii mystetstv Bulletin of the Lviv Academy of Arts, 12, 296-301 [in Ukrainian].

18. Chebykin, A. (2018). Nezghasne svitlo doli [The fading light of fate]. Visnyk Zakarpatskoi akademii mystetstv - Bulletin of the Transcarpathian Academy of Arts, 11, 7 [in Ukrainian].

19. Shmahalo, R. (2018). Tvorcho-pedahohichnyi fenomen Emmanuila Myska [The creative and pedagogical phenomenon of Emmanuil Mysko]. Visnyk Zakarpatskoi akademii mystetstv - Bulletin of the Transcarpathian Academy of Arts, 11, 11-14 [in Ukrainian].

20. Yatsiv, R. (2018). Skulptor Emmanuil Mysko: svitlo doli [Sculptor Emmanuil Mysko: the light of fate]. Visnyk Zakarpatskoi akademii mystetstv - Bulletin of the Transcarpathian Academy of Arts, 11, 9 [in Ukrainian]. 


\begin{abstract}
ANNOTATION
Mariia Hlushko. Representation of Emmanuil Mysko's works on the pages of art magazines. This paper analyzes art magazines and other periodicals in the context of the presentation of works by the famous sculptor Emmanuil Mysko, who holds a special place in the fine arts of Ukraine. The research material provides a brief overview of publications in art magazines and other periodicals that thoroughly acquaint the reader with the formation and evolution of Emmanuil Mysko's creative path. The focus is made on a holistic analysis of articles by art historians describing the artist's work, as well as publications containing only specific references to him. A number of well-known national art magazines, newspapers, newsletters, etc. covering the cultural and artistic events were selected for the study, namely, the magazine of the National Union of Artists of Ukraine "Fine Arts", "Art" magazine, "Free Ukraine" newspaper, Bulletin of the Lviv National Academy of Arts, "People's Notebooks", "Art Horizons" and others.

Emmanuil Mysko's activity in the field of monumental and decorative sculpture and to emphasize his contribution to the development of Ukrainian art. It is revealed that the talent, pedagogical and social activity, human qualities of Emmanuil Mysko and its impact on culture and art, have not been neglected by national scientists, art historians, researchers who in their works published on pages of art magazines and other periodicals describe various aspects of the life and work of a prominent Ukrainian sculptor, art critic, teacher, public figure Emmanuil Mysko. The need to create a structured bibliographic index has been identified, which will contain a complete list of articles on E. Mysko published since 1996, since the Bibliographic Index was published by that year. Also the main provisions and conclusions of the article can be used in the formation of the relevant sections of the new Bibliographic Index, which will become a basis for young researchers who will study the work of E. Mysko.
\end{abstract} The study outlines a number of trends regarding the presentation of material about Emmanuil Mysko, through which it can be argued that each of the authors tried to highlight as much as possible the key aspects of
Key words: art journal, periodical, scientific collection, creative work of Emmanuil Mysko's, monumental and decorative sculpture, portrait. 